\title{
計測用装具を用いた痙性麻痺の歩容解析に関する研究*
}

\author{
嶺也守寛*1，小林 吉 之*1 $^{* 1}$ \\ 高 嶋 孝 倫*2, 藤 本 浩 志*3
}

\section{Research on the Gait Analysis of the Spastic Paralysis using the Measurement Orthosis}

\author{
Yasuhiro MINE*4, Yoshiyuki KOBAYASHI, \\ Takamichi TAKASHIMA and Hiroshi FUJIMOTO \\ ${ }^{* 4}$ Graduate School of Human Science, Waseda University. \\ 2-579-15 Mikajima. Tokorozawa-shi, Saitama, 359-1192 Japan
}

\begin{abstract}
We developed the SMO (Spastic Measurement orthosis) in order to measure the feature of spasticity by the paralysis of stroke. Because we focused on patients suffering from hemiplegics stroke in order to develop a design method of an AFO, which fit patients even more. Experiment method: Experiment system was consisted combining 3D Video Tracking system of $12 \mathrm{CCD}-$ camera and 8 force plates and SMO. Subjects of the experiment were conducted by healthy person and four stroke persons. Each subject who wore the SMO walked on the floor reaction force by usual walk. Experiment Result: Each subject's ankle joint moment was calculated and these experiments data were evaluated by comparison of the moment of SMO and foot angle at the Heel contact, paying attention to heel contact required for orthosis prescription. The possibility in order to determine of requirements for the design orthosis was suggested from these experiment results.
\end{abstract}

Key Words: Human Engineering, Measurement, Design, Spasticity, Hemiplegics Gait

\section{1. 緒言}

脳血管障害 (脳卒中) は我が国の 3 大死因の 1 つ であり平成 14 年度の厚生労働省の統計調査 (1) では 137 万人の患者数が存在する. 脳卒中片麻㾝の特徴と して痙性と呼ばれる下腿三頭筋の異常緊張により足関 節部が底届した尖足となり歩行困難な状態を招き，装 具なしの状態では歩行不安定や転倒を招くことになる. また，外部刺激によって周期的な笳収縮により足ク口 一ヌスを発生することが判っている，㽷性の評価法と しては, Letmann ${ }^{(2)}$ らによる $D$ モータとクランク機構

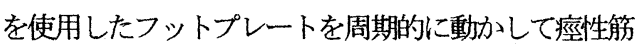
の特性を計測する手法が採られていた。近年では野平 $ら^{(3)}$ が行った足部背屈装置を利用しての筋電による 測定が行われている. しかし，これらの計測は歩行で はなく特定の姿勢を保った状態での計測であり, 装具

* 原稿受付 2006 年 3 月 20 日.

*1 正員, 早稲田大学大学院人間科学研究科(业 359-1192 所沢 市三ヶ島 2-579-15).

*2 正員. 国立身体障害者リハビリテーションセンター学院 (䡤359-0042 所沢市並木 4-1)

*3 正員. 早稲田大学大学院人間科学学術院.

E-mail : mine@akane.waseda.jp
処方には適用できない，臨床の場面では, 麻㾝の程度 を Modified Ashworth scale ${ }^{(4)}$ や Brunnstrom stage ${ }^{(5)}$ な どを用いて徒手的な評価を行って定量化するが，これ らの評価法においても装具設計のために直接的に有用 なパラメータを得ることは困難である. 装具機能の目 的としては，片麻䅛によって生じた歩行機能障害の代 償または補助であり, 歩容の安定化のために歩行状態 に合わせた底屈を防ぐ装具の矯正モーメントが必要で ある. 本来は足関節痓性によって生じる歩行中のモー メントを計測し，それに適応した矯正モーメントを持 つ装具の設計が必要であるが現状はそこまでは至って ない. 山本ら ${ }^{(6)}$ は複数のバネを用いて装具の可撓性 をパラメータとし床反力から求めた足関節モーメント を筋力によるモーメントと装具による矯正モーメント に分離できることを示した. 但し, 個々の片麻斬者の 足関節の運動特性に合わせた装具の適用を考えると， 実際に歩行動作中における足関節の痸性麻㾝の状態を 定量的に評価しなければならない，そこで本研究では， 計測用装具 (Spastic Measurement Orthosis : SMO) の開 
発を行い，步行実験結果から痓性の筋緊張異常による 歩容への影響を足関節底背屈モーメントを用いて定量 的に評価することを目的とする. 具体的には立脚初期 の踵接地時に着目し，この時の底屈モーメントの計測 值と接地角から各被験者による痙性麻㾝による歩容の 不安定性の評価を試みる. このように歩行中の患者の 足関節モーメントの特性を定量的に記述できるように なれば個々の患者に適した装具の構造設計に適用する ことも可能となる.

\section{SMO(Spastic Measurement Orthosis)の製作}

脳卒中片麻痹に起こる痤性の特徵を計測するため, 図 1 に示寸計測用装具 (Spastic Measurement Orthosis: SMO )を開発した. SMO は足関節部においてはフリ ージョイントであるが，装具背面に取り付けられた口 一ドセルによって足関節姿位 $90{ }^{\circ}$ ] としたメカニカル ロック機構としている.これにより足関節運動は生じ ないが痙性によって発生するモーメントを計測するこ とができる. 静止立位時をニュートラル位置とし，そ れより足関節底屈方向のモーメントが作用すれば縮 荷重となり負の荷重値が出力され, 逆に背届方向の場 合には引張荷重となり正の荷重が出力される. SMO による足関節モーメントはジョイント中心部からロー ドセル位置までの垂線距離をモーメントアームとしロ 一ドセルの出力値との積で算出される. SMO を用い， 装着しない状態で Heel-Contactから ToeOffまでを想

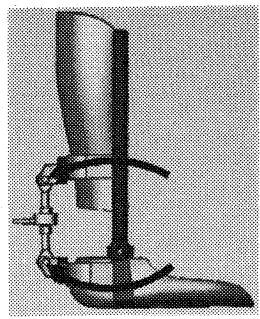

Compressive loads

(Plantar-flexion Moment)

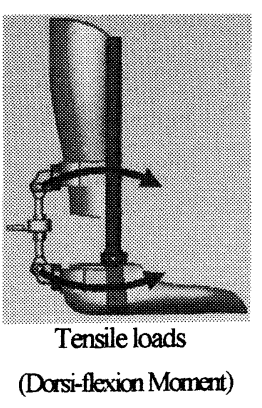

(Dorsi-flexion Moment)
Fig. 1 Function of SMO

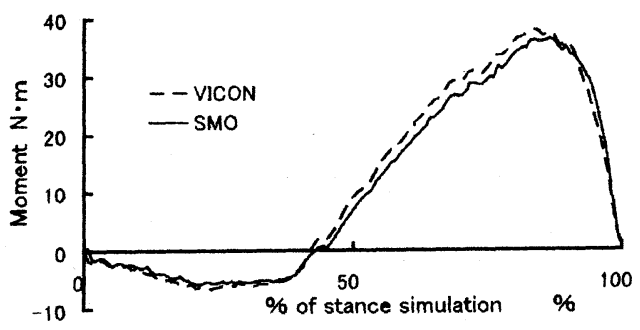

Fig. 2 Verification of SMO
定して荷重を印加しモーメントを算出した. 同時に 3 次元動作計測装置と床反力計から得られたデータを用 いて逆動力学解析によりモーメントを算出した．両者 を比較することで SMO の妥当性を検証した．検証結 果 (図 2 参照) から，機構的誤差等によりわずかな差 異が認められるが，ほぼ等価であることが確認できる. なお, SMOの総重量は約 $1.0[\mathrm{~kg}$ ]で装着時の違和感等 は認められない。

\section{3. 歩行実酫}

\section{$3 \cdot 1$ 健常者による歩行実検}

$3 \cdot 1 \cdot 1$ 実検方法 足関節㾏性麻㾝の特性の定量 化するための比較対象として健常者による歩行実験を 行った. 実験では, SMO と 12 台の赤外線カメラで構 成される 3 次元動作計測装置 (VICON512 OXFORD METRIX) と床反力計( AMTI)とを用いて計測を行っ た. SMO の出力信号は 3 次元動作計測装置の $\mathrm{AD}$ 変 換ボードにアンプを介して直接入力しており完全に同 期したデータとして記録される. 図 3 に実験の様子を 示す.

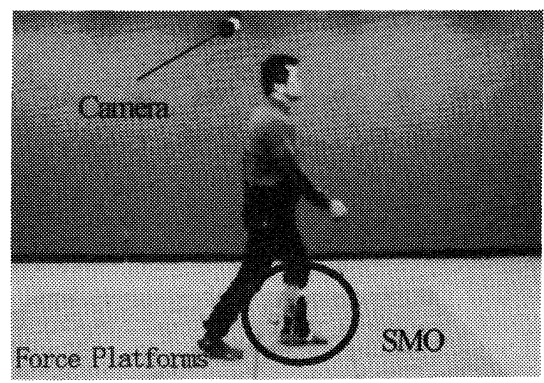

Fig. 3 The situation of experiment

実験方法は, SMO を装着し, 床反力計（8 枚で歩 行路を構成) の上を通常どおり歩行を行った. 両側の 股関節、滕関節、足関節、第 5 中足骨頭、踵の各特徴 点に反射マーカを取り付け, 3 次元動作計測装置で 60[Hz]のサンプリング周期で計測を行った. SMO に はジョイント中心を足関節部としてマーカを取り付け ている.これら 3 次元動作計測装置の位置データと床 反力計の力データより足関節周りのモーメントを求め た. また，睡接地時の接地角度は中足骨頭と踵のマー 力座標値より求めた.

$3 \cdot 1 \cdot 2$ 実酫結果 SMO の出力と同時に計測した床 反力計鈆直方向成分の結果を図 4 に示す. 床反力のデ 一夕から, 踵接地 $(\mathrm{HC})$, 足底接地 $(\mathrm{FF})$, 踵離地 (HO)，つま先離地（TO），遊却中期（MS），踵接地 前 $(\mathrm{DC})$, 立脚期 $(\mathrm{HC} \sim \mathrm{HO})$, 遊脚期 $(\mathrm{TO} \sim \mathrm{DC})$ の夕 イミングを定めることができ，また，図 5 は健常者の 
1 歩行周期のおける足関節モーメントと.SMOによって 計測されたモーメントを示している.ここで横軸は踵 接地から次の踵接地までを正規化してある. この健常 者の 1 歩行周期の歩行パターンについて Vaughan ら (7) が行った歩行分析にも対応している. ここで 3 次 元動作計㵋装置と床反力計から算出されるモーメント とSMOによるモーメントとの関係は，立脚期において はその差が筋力によって足関節が発揮したモーメント であり，遊脚期においては SMD の正の出力は前脛骨筋 によってつまずきを防ぐために背屈させるモーメント を表している.これは山本ら (8)方提晿している差に よる筋力のモーメントと一致する，なお、本実験は、 早稲田大学における人 (人間) を対象とした研究に 関する倫理指針」を遵守したものである.

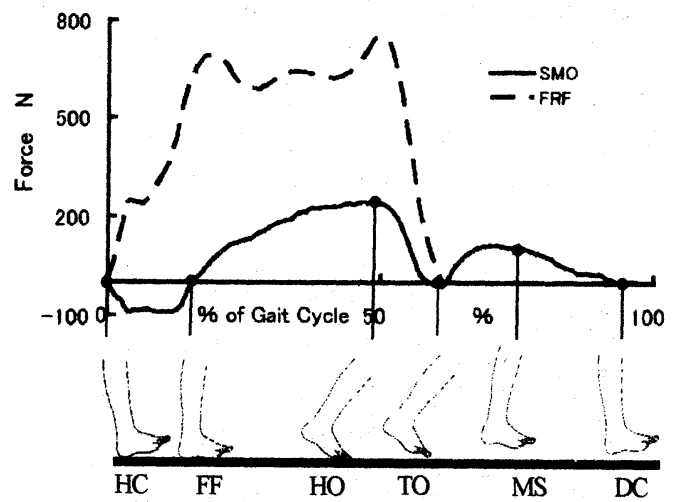

Fig. 4 The load of SMO transducer and the floor reaction force

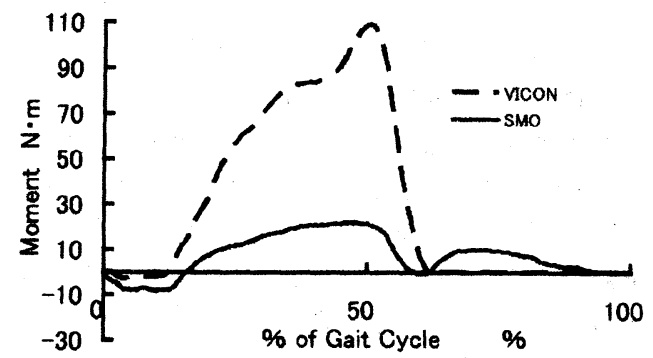

Fig. 5 Moment of SMO

\section{3 -2 脳卒中片麻墘者による実験}

$3 \cdot 2 \cdot 1$ 実験方法 健常者による実験におい て,SMD の機能と安全性を十分に確認したうえで，BRS (Brunnstrom Recovery Stage) III, IVレベルの脳卒中片麻 㾝者 4 名の協力を得て歩行実験を行った. 表 1 に各被 験者の状態を示す．被験者は腱延長術等の足関節機能 再建手術を施されてない者を対象としている，被験者 の歩行実験においては，実験方法は，3・1 に示寸健 常者による步行実験と同様のシステムを使用し，SMO を装着したのち床反力計で構成される歩行路（約 3[m]）上を通常歩行で 30 試行の歩行を行った. 各被 験者とも步行実験前に調査した事前デー夕に関する事 項と足関節の状態を以下に示す.

被験者 $\mathrm{A}$ は，痤性麻庫による足関節の状態としては 他動での底背届が可能であり比較的軽度と判断される。 装具非装着でも近距離の歩行は可能である. 外出時に は金属支柱型装具を使用しているが，装具を着脱時に 足クローヌスが発生することがある.

被験者 B は，他動での底背屈が若干可能であり自動 でも底背屈が可能であった．外出時には金属支柱型の 装具を装着している.

被験者 C は，足関節は自動で動かす際にも背届指示 に対して底屈位になるなど明らかな筋緊張異常が見ら れた．他動においても底背届が困難であった．

被験者 D は，比較的痓性麻㾝の強い傾向で足関節は 拘縮に近い状態であった. 外出時は車椅子を使用して おり，金属支柱型装具を常用している. 実験時には安 全のため杖を使用して行われた。

\section{$3 \cdot 2 \cdot 2$ 実験結果 各被験者のストライド長の平} 均は, A:0.71[m], B: $0.50[\mathrm{~m}], \mathrm{C}: 0.38[\mathrm{~m}], \mathrm{D}: 0.49[\mathrm{~m}]$, 健常者 $(\mathrm{HP})$ は $1.13[\mathrm{~m}]$ であった. 4 名の片麻煌者による 步行実験の結果を図 6 に示寸. 檤軸は 1 歩行周期の SMO の計測値から求めた足関節モーメントを示してい る. 正の值が背屈方向, 負の值が底屈方向を示す. ま た，TO は装具装着側の下肢が離地したタイミングを 示している. なお, 各グラフには 30 試行中の各被験 者の特徴を示す 3 試行分を挙げている.

Table. 1 The profiles of 4 subjects

\begin{tabular}{c|c|c|c|c}
\hline Subject & A & B & C & D \\
\hline Sex / Age & Male / 51 & Male / 58 & Male / 56 & Male /61 \\
\hline Body Weight [kg] & 65.2 & 72.3 & 70.5 & 60.6 \\
\hline Years Since Stroke & 2.5 & 1.5 & 2 & 10 \\
\hline Spasticity & Mild & Medium & Severe & Severe \\
\hline
\end{tabular}


被験者 Aのモーメントの特徴としては，各試行とも 立脚中後期に背屈モーメントが見られる. 全試行にお いて変動が大きいのはHC〜FFでの区間であった.

被験者 B のモーメントとしては，立脚中後期に背屈 モーメントが見られる. 各試行とも大幅な変動はなく 歩行としては安定していることがわかる. 立脚初期の 踵接地の底屈モーメントは大きくない，遊却期におい ては足関節の底背屈モーメントがほとんど見られず足 部重量程度でほほ静止立位角度を保持している。

被験者 Cの実験結果のモーメントには，大幅な変動 が見られ，非常に不安定な歩行であることがわかる. 遊却期は時折痙性よる尖足が確認される.

被験者Dの計測されたモーメントは各圾行で大幅な 変動は見られないが立脚全域に周期的な底背屆モ一メ ントが発生しており病性の六進が見られる. 立脚中期 での背屈モーメントが発生することはなかった。遊却 期においても同様に尖足が確認された。

\section{4. 考 察}

各被験者の歩行実験結果から, 症性麻禈が歩容に及 ぼす影響について考察する. 山本ら (8) (9) が行った 装具処方における要件としては, 立脚初期の制動モ一 メントなどが重要視されている. そこで本実験結果か ら踵接地時の接地角度と底屈モーメントとが歩容に及 ぼす影響を考える．なお，接地角度とは踵接地時にお
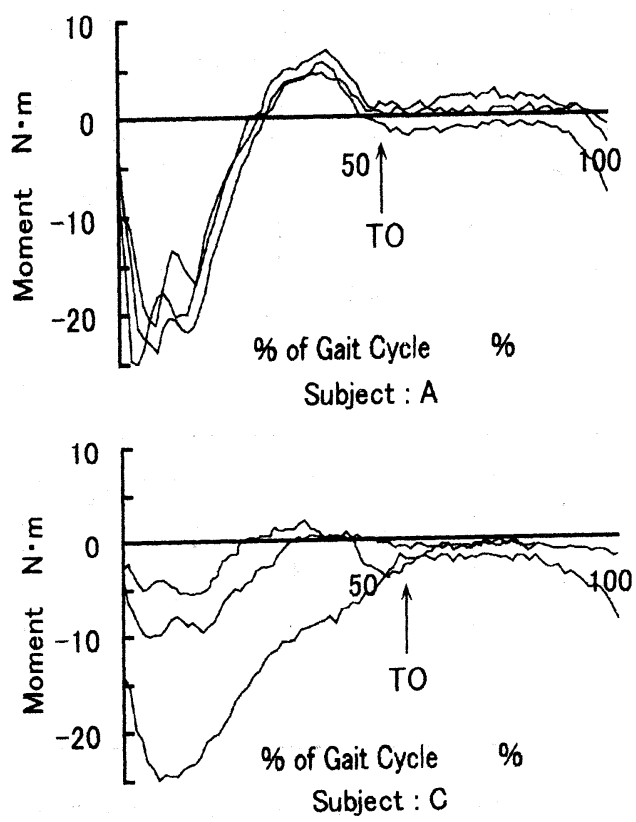

ける床面と足底との角度を意味する. 図7には接地角 とSMOの底屈モーメントとの関係を散布図で示した。 これらを比較すると被験者 B の歩行が健常者の約 $1 / 2$ のストライド長 (SD:0.035lml) であるが, ある程度の 再現性を保ちながら歩行を行っていることがわかった. これは麻瘦側の上下肢及び足関節の状態が比較的良好 て踵接地に対しても衝揧を緩和でき，步行訓練によっ て自らの安定性を会得していると考えられる. 被験者 Cでは広範囲でばらつきが確認できる. 時には接地角 度 0 度以下の尖足状態が確認できる.これは通常の踵 接地ではなく, 逆につま先で接地している状態を表し ている. 被験者A は装具なしでも歩行可能であるが, 底屈モーメントにばらつく傾向が見られ下腿三頭筋の 筋緊張異常により踵接地における衝擊吸収が適切でな いと考えられる. 被験者 Dは, 接地角, 底屈モーメン ト共にばらつく傾向があるが，実駼時に杖を使用した ことによって安定性が得られている. 杖の歩行形式は， 前方三動作歩行を用いており, 步行訓練にて会得され たものである. 図8は踵接地時の接地角度およひ底屈 モーメントの平均值と偏差の最大範囲を示す. 1 は は 健常者である. また，接地角度の SD は、A:2 $\left.41^{\circ}\right]$, $\left.\left.\left.\mathrm{B}: 1.7^{\circ}\right], \mathrm{C}: 5.77^{\circ}\right], \mathrm{D}: 2.6^{\circ}\right], \mathrm{PP}: 1.3\left[^{\circ}\right]$ ]゙あり, 底 屈モーメントの SD は, $\mathrm{A}: 4.1[\mathrm{~N} \cdot \mathrm{m}], \mathrm{B}: 1.2[\mathrm{~N} \cdot \mathrm{m}]$, $\mathrm{C}: 4.5[\mathrm{~N} \cdot \mathrm{m}], \mathrm{D}: 2.6[\mathrm{~N} \cdot \mathrm{m}], \mathrm{HP}: 0.4[\mathrm{~N} \cdot \mathrm{m}]$ であった. 健常者步行では，平均接地角が大きく，SDが小さい
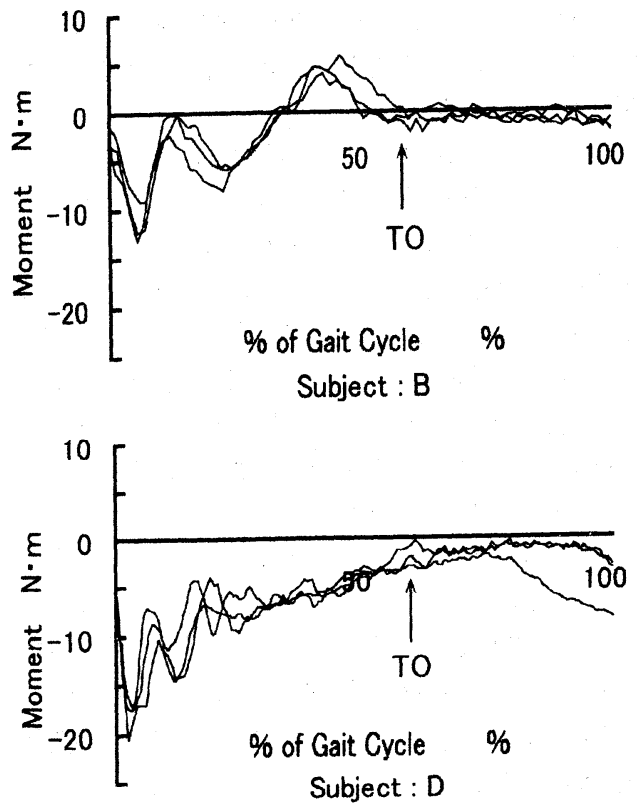

Fig. 6 Ankle Joint Moment by SMO 

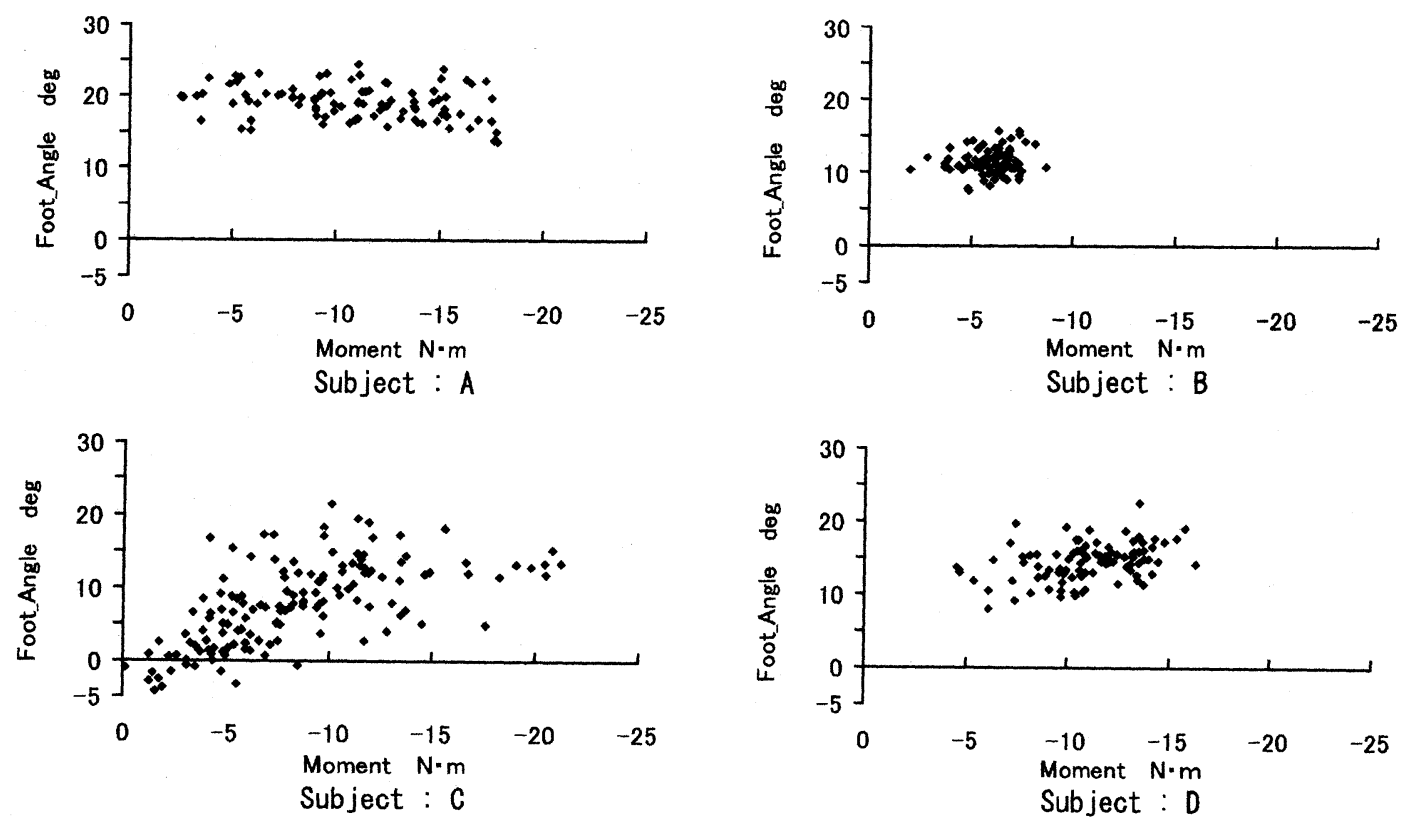

Fig. 7 Comparison of foot angle and ankle joint moment (Heel Contact)

ことから足の振り出しが十分に行われ安定した歩行が 実現できていることがわかる。 また，モーメントにつ いては平均値としてもほとんど顕著な值が認められず, SD も小さいことから, やはり再現性の高い動作であ ることがわかる．被験者 A は日頃からの歩行訓練によ つて下肢が訓練されているために下肢の振り出しは可 能だが, 痙性麻㾝の影響により足関節が踵接地におけ る衝撃吸収が困難であると考えられる。.また，計測用 装具の装着前に足クローススの発生が認められた。被 験者 B は理学療法士による歩行訓練プログラムを受け た後 6 ケ月が経過しており, 被験者の中でも退院後最 短である. 前述に示す様に実験前の足関節の状態では 底背屈位も確認しており被験者の中では比較的軽度と 考えられる. 被験者Cの足関節状態は, 背屈指示に対 して底屈になるなど明らかに下腿三頭筋のコントロー ルが困難な状態を確認している. また, 視床下部付近 の脳出血であり軽度の高次脳機能障害と診断されてお りその影響も考えられる. 大きな特徴としてはいずれ もSD が顕著に大きな值を示しており極めて再現性の 低い動作であることがわかる. 最低接地角は約一 5.0[deg]にもなり痙性の筇緊張異常より歩行パターン の異常が顕著に出現している. 被験者 Dでは, 足関節 の自動は不可であり他動に関しても拘縮㑯向にある. 以上の通り, 実験結果からは脳卒中片麻瘪の各被験者 における足関節の底背届の状況を詳細に得ることがで
き, 痙性麻㾝の特徵を定量的評価の可能性を示すこと ができた．個々の片麻椑者に適合した装具を製作する 際に参考となる知見として以下のことが考えられる. 例えば, 被験者 Bは, 比較的安定した歩行であり底屈 モーメントも大きくないうえ立脚中後期には健常者と 同様に背屈モーメントも確認できるので Flexible ankle type の装具が適用できると判断できる.

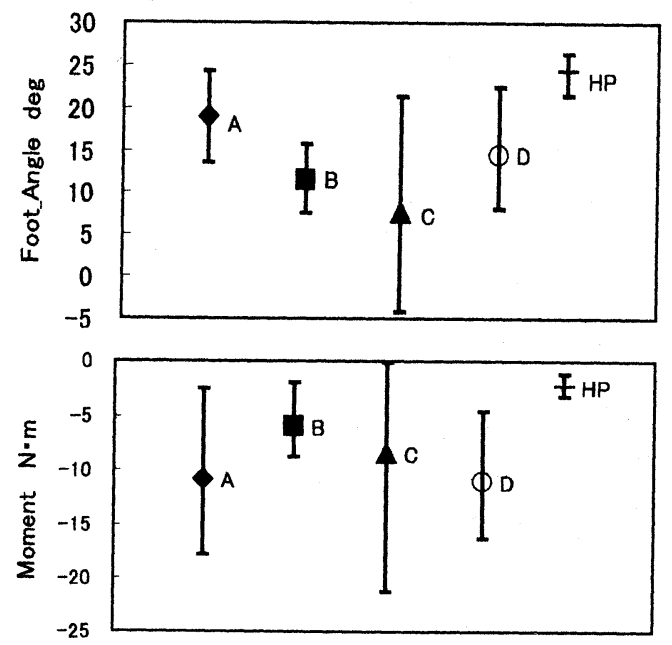

Fig. 8 Average of foot angle and ankle joint moment (Heel Contact) 
被験者Cのような接地角に大幅なばらつきがある場合， 尖足による転倒も危惧されるので Rigid ankle type の 装具が求められるであるう。被験者 $\mathrm{A}$ は, 接地角は十 分にあるが底屈モーメントにばらつきが見られるので Flexible ankle type の装具を適用できるが，踵接地に おける衝揧に耐えるだけの強度が必要である. 被験者

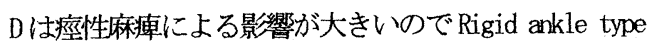
の装具で対応が可能ではないかと考えられる.

\section{5. 結 言}

本研究では, 歩行中の痙性麻㾝の特性を定量化する ためにSMO の開発を行い，足関節における底届背屈モ 一メントを計測するシステムの構筑を行った. 本計測 システムを用いて歩行実験を行い，特に装具処方に必 須な立脚初期の踵接地に注目して歩行解析を行った. 装具設計での必要事項としては，歩行中の立脚期，遊 脚期に执、痙性麻痻よる底背屈を装具の可撓性によ って補う必要がある. その度合は装具のニュートラル 位置が基準となる。ここでは, 従来の装具研究にある 製作された装具に対しての評価ではなく，個々の片麻 㾇者の特性に適した装具を設計するために片麻㭦者ご との足関節の特性を定量的に評価する一手法を構筑し た. 今後は足部の 3 次元形状データを基に 3 次元 CAD による装具の構造設計を行い，本研究で得られた歩行 中の㽷性による足関節底屈モーメントの特性を境界条 件として用いた構造解析によって可撓性と応力集中の 関係などの評価を行い，より適切な装具設計手法を提 案していく予定である.

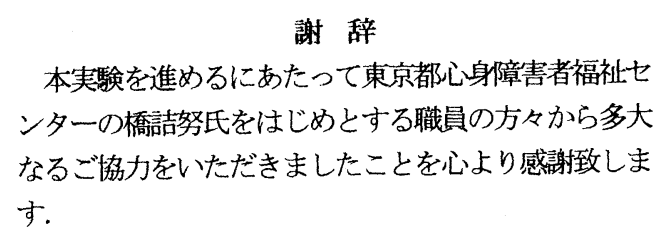
ンターの橋詰努氏をはじめとする職員の方々から多大 なるご協力をいただきましたことを心より感謝致しま す.

\section{文 献}

(1) Datahase of statistical table, Ministry of Health, Labor and welfare, Patient investigation in $2002 \mathrm{~N}$. 3. 3, 92table, The total number of patients sex - Age class $\times$ Sickness-andwound classification http://wwwbtk. mhlw. go. jp/toukei/

(2) Lehmann. J.F, Robert. P, Barbara. J.d, Spasticity: Quantitative Measurements as a Basis for Assessing Effectiveness of Therapeutic Intervention, Arch Phys Med Rehabil, Vol.70, (1989)
(3) Nohira. H, et al, Spasticity appraisal method using the simple equipment of ankle dorsiflexion (in Japanese), Biomechanism symposium (1993) pp. 71-78

(4) Ueda B, Rehabilitation medicine seen by the eye (in Japanese) (1968), p. 17, Takeda Pharmaceutical Company Limited

(5) Brunnstrom S, Mbvement therapy in hemiplegia, A Neurophysiological Approach, (1970) p 34, Haper and Row

(6) Yamamoto $S$, et al, The Effects of the flexibility of ankle-foot-orthoses on gait(in Japanese), Biomechanism10, (1990) pp 195-204

(7) Vaughan C. L, Davis. B. L, O' Connor. J. C, Dynamics of Human Cait, (1992), Htman Kinetics Publishers

(8) Yamamoto. S, Ebara Y, Introduction to BodyDynamics, Hemiplegic Gait and Ankle Foot Orthosis (in Japanese), (2005), p. 95, ISHTYAKU Publishers $\mathbb{N C}$

(9) Ebara $Y$, et al, Biomechnics of Ankle Foot Orthosis (in Japanese), Japanese Society of Prosthetics and Orthotics (2002) p. 18, ISHIVAKU Publishers $\mathbb{N} \mathbb{C}$ 